\title{
Implementasi Kemandirian dan Jiwa Sosial (Life Skills) Santri di Pesantren
}

\author{
Riyan \\ UIN Sunan Kalijaga Yogyakarta, Indonesia \\ Riyanjayaputra04@gmail.com
}

\begin{abstract}
Abstrak:
Lembaga pendidikan di Indonesia pada umumnya mengharapkan lulusannya untuk mendapatkan lapangan pekerjaan yang sesuai dengan bidang yang ditekuni ketika menuntut ilmu. Namun harapan tersebut hanya sebagian kecil dari pendidikan yang ada di Pondok Pesantren yang mana mengharapkan lulusannya menjadi santri yang memiliki kemampuan atau kecakapan mandiri, memiliki jiwa sosial dan solidaritas yang tinggi, baik budi pekerti, berbakti kepada kedua orang tua dan mengabdi kepada bangsa, Negara serta Agama. Oleh karena itu pentingnya peran dan fungsi Pesantren agar memberikan bekal kecakapan hidup (life skills) personal dan sosial. Kecakapan hidup personal dan sosial yang diajarkan di Pondok Pesantren di antaranya ialah kemandirian santri dan mengembangkan jiwa sosial (saling tolong menolong dan menumbuhkan jiwa kerja sama sesama santri). Penelitian ini merupakan penelitian kualitatif, dengan metode observasi, wawancara dan dokumentasi. Hasil penelitian menunjukkan bahwa pertama, strategi Pondok Pesantren Pangeran Diponegoro dalam pengembangan kemandirian santri yaitu Kiai dan para pengasuh memberikan nasehat, melatih jiwa kepemimpinan santri, membiasakan santri dalam melakukan aktivitas sesuai peraturan, keteladanan dari Kiai. Kedua, strategi dalam pengembangan jiwa sosial dengan membiasakan santri peduli, menjaga kebersamaan, berinteraksi, serta berperilaku simpati dan empati.
\end{abstract}

Kata Kunci: Pesantren, Kecakapan Hidup (Life Skill), Kemandirian, dan Jiwa Sosial

\begin{abstract}
:
Education institutions in Indonesia generally expect the graduates to obtain jobs that are in line with the areas in which they are engaged when studying. But the hope is only a small part of the education in islamic boarding school which is expecting the graduates to be students who
\end{abstract}


have the ability or self-skills, have a high social spirit and solidarity, good manners, Devoted to both parents and dedicated to the nation, state and religion. Therefore, the importance of the role and function of islamic boarding school to provide personal and social life skills. Personal and social life will be taught in Pondok Pesantren including the independence of students and the development of social souls (mutual help and foster the spirit of fellow students cooperation). This research is a qualitative study, with observation methods, interviews and documentation. The results show that first, the strategy of islamic boarding school Pangeran Diponegoro in the development of students independence is Kiai and the caregivers give advice, train the spirit of students leadership, familiarize the students in doing Activities in accordance with the regulations, the example of Kiai. Secondly, the strategy in social soul development by familiarizing students cares, maintaining togetherness, interacting, and behaving of sympathy and empathy.

Keyword: Boarding School, life skills, independence, and social souls

\section{Pendahuluan}

Pendidikan di Pondok Pesantren terkenal dengan pendidikan agama yang diajarkan oleh sosok seseorang yang mempunyai karisma tersendiri yang biasa dikenal oleh khalayak umum dengan Kiai. Kiai sosok seseorang yang berpengaruh dan menjadi panutan di Pondok Pesantren. ${ }^{1}$ Para pelajar yang diajarkan oleh kiai disebut santri. Kata santri berasal dari bahasa Sanksekerta yang berarti melek huruf dan dari bahasa jawa "cantrik" yang berarti seseorang yang menetap disuatu tempat dan menuntut ilmu untuk menambah wawasan/pengetahuan. ${ }^{2}$ Tujuan pendidikan di Pondok Pesantren telah sesuai dalam undang-undang RI No 1 Tahun 2013 Pasal 1dalam Sistem Pendidikan Nasional tentang tujuan pendidikan adalah usaha sadar dan terencana untuk mewujudkan suasana belajar dan proses pembelajaran agar peserta didik secara aktif mengembangkan potensi dirinya untuk memiliki kekuatan spiritual keagamaan, mengendalikan diri, kepribadian, kecerdasan, akhlak mulia, serta keterampilan yang diperlukan dirinya, masyarakat, bangsa dan negara. ${ }^{3}$

Jika dilihat pendidikan di Indonesia saat ini sudah terpengaruh oleh budaya barat, seseorang menjadi manja, pudarnya jiwa sosial seseorang, hilangnya sopan santun, hilangnya saling menghargai sesama manusia, dan berkurangnya akhlak serta keterampilan seseorang

\footnotetext{
${ }^{1}$ Shofwatin Ni'mah, 'Pelaksanaan Pendidikan Life Skills di Pondok Pesantren Darul Falah BeSongo Ngaliyan Semarang’. (Skripsi, Institut Agama Islam Negeri Walisongo, 2012).

${ }^{2}$ Risqi Respati Suci Megarani, 'Strategi Pemberdayaan Santri di Pondok Pesantren Hidayatullah Donoharjo Ngaglik Sleman Yogyakarta’. (Skripsi, UIN Sunan Kalijaga, 2010).

3 Ibid., hal. 1.
} 
Riyan

dalam bertingkah laku. ${ }^{4}$ Pondok Pesantren sebagai pusat lembaga pendidikan yang mengajarkan ilmu agama Islam berfungsi untuk mengakomodir budaya barat tersebut. Pesantren juga dituntut untuk mengikuti zaman, menyesuaikan kebutuhan lulusan pondok pada masa yang akan datang, dalam hal ini Pesantren memiliki strategi mengembangkan kecakapan hidup santri. Kecakapan hidup (life skill) adalah bekal dasar yang ada pada diri santri yang diberikan oleh Pesantren untuk masa kini dan yang akan datang serta santri dapat menyelesaikan permasalahan hidup santri itu sendiri. ${ }^{5}$

Pesantren telah berkontribusi memberikan berbagai macam kecakapan hidup kepada santri diantaranya kecakapan hidup personal, kecakapan hidup sosial, kecakapan hidup akademik dan kecakapan hidup vokasional. Namun berbeda dengan lembaga pendidikan luar Pesantren yang hanya membekali siswanya dengan kecakapan hidup akademik dan kecakapan hidup vokasional yang mengarahkan siswanya untuk dapat menguasai bidang pekerjaan tertentu. Oleh karena itu untuk meningkatkan kualitas diri dan jiwa sosial santri agar bertahan hidup dalam masyarakat perlu adanya pemantapan kecakapan hidup personal dan kecakapan hidup sosial santri serta keterampilan yang tidak hanya mengarahkan ke bidang pekerjaan tertentu. ${ }^{6}$ Pernyataan ini senada dengan Anwar dalam karya ilmiah Muhammad Adil Arnady dan Lis Prasetyo yang menyatakan pada dasarnya kecakapan akademik lebih mengarah kepada keilmuan dan vokasional terkait dengan pekerjaan yang memerlukan keterampilan motorik. ${ }^{7}$

Salah satu ciri kecakapan hidup personal yang dibiasakan di pesantren adalah membentuk kemandirian santri. ${ }^{8}$ Kemandirian adalah kondisi seseorang untuk tidak menggantungkan diri kepada orang lain, karena ketidakmandirian seseorang sering dikaitkan dengan mengharapkan orang lain. Pendidikan di pesantren tidak hanya tempat transfer ilmu tetapi tempat untuk menumbuhkembangkan jiwa santri dengan keterampilan, kemampuan dan karakter. ${ }^{9}$

${ }^{4}$ Imam Suyitno, "Pengembangan Pendidikan Karakter dan Budaya Bangsa Berwawasan Kearifan Lokal.” Jurnal Pendidikan Karakter 2, no. 1 (2012), hal.1-13.

5 Syarifatul Marwiyah, "Konsep Pendidikan Berbasis Kecakapan Hidup." Jurnal Falasisfa 3, no. 1 (2012), hal. 75-97.

${ }^{6}$ Imam Mawardi, "Pendidikan Life Skills Berbasis Budaya Nilai-Nilai Islami dalam Pembelajaran." Jurnal Pendidikan Islam 6, no. 2 (2012), hal. 215-230.

7 Muhammad Adil Arnady dan Lis Prasetyo, "Evaluasi Program Kecakapan Hidup di Sanggar Kegiatan Belajar Bantul Yogyakarta.” Jurnal Pendidikan dan Pemberdayaan Masayarakat 3, no. 1 (2016), hal. 6o-74.

${ }^{8}$ Uci Sanusi, "Pendidikan Kemandirian di Pondok Pesantren." Jurnal Pendidikan Agama Islam 1o, no. 2 (2012), hal. 123-139.

${ }^{9}$ Tut Sayogya, Sukses Berbasis Talenta Alami, (Jakarta: PT Elex Media Komputendo, 2011), hal. 207. 
Kemampuan seseorang dalam menyelesaikan permasalahan dalam hidup sangat diperlukan, karena dengan adanya kecakapan hidup, seseorang sudah bisa dikatakan mandiri. Disisi lain kecakapan hidup sosial juga sangat penting dalam kehidupan, karena bagaimanapun juga manusia merupakan makhluk sosial yang tidak dapat hidup tanpa bantuan orang lain. Ketika membahas kecakapan hidup sosial yang mengarah kepada kerjasama dan tolong menolong seseorang tidak terlepas dari komunikasi. Komunikasi adalah interaksi sesama manusia agar terjadi bertukar informasi. Komunikasi yang baik akan menghasilkan keharmonisan, dan komunikasi yang kurang baik akan menimbulkan pertikaian. Upaya yang dilakukan pesantren agar mengembangkan kecakapan santri dari segi sosial, diantaranya adalah santri dididik untuk belajar berorganisasi dan melatih diri berbicara di depan orang banyak (pidato). ${ }^{10}$

Oleh karena itu di Pondok Pesantren Pangeran Diponegoro memiliki keunikan dari visi misi yang berkaitan dengan melatih dan mengembangkan kecakapan hidup personal yang mengarahkan santri untuk mandiri dan melatih jiwa sosial santri yang membangun jiwa tolong menolong dan kerjasama sesama santri serta peka terhadap lingkungan. Oleh karena itu, Pondok Pesantren Diponegoro mengakomodir kecakapan hidup personal kemandirian dan kecakapan hidup bersosial yang mengarah kepada kemandirian, cara bekerja sama, bertanggung jawab serta tolong menolong.

\section{Konsep Pesantren}

Menurut Clifford Geertz pesantren adalah a place for peripatetic Islamic students or santri. ${ }^{11}$ Menurut M Arifin pesantren adalah lembaga pendidikan agama Islam yang tumbuh serta diakui masyarakat, dengan sistem asrama dimana santri mendapatkan ilmu melalui pengajian dan sistem kelas yang diajarkan oleh seseorang Kiai yang bersifat karismatik. ${ }^{12}$ Pondok Pesantren merupakan institusi sosial keagamaan yang menjadi wahana pendidikan bagi umat islam yang mendalami ilmu-ilmu keagamaan. ${ }^{13}$

Secara umum pesantren memiliki ciri-ciri, yang dikutip dari Ziemek dalam karya Syamsul Ma'arif yaitu pertama, kiai sebagai pendiri, pelaksana, dan guru. Kedua, santri

${ }^{10}$ Tut Sayogya, Sukses Berbasis Talenta ..., hal. 47.

"Syamsul Ma'arif, Pesantren Inklusif Berbasis Kearifan Lokal, (Yogyakarta: Kaukaba Dipantara, 2015), hal. 19.

${ }_{12}$ Mujamil Qomar, Pesantren dari Transformasi Metodologi Menuju Demokratisasi Instutusi, (Jakarta: Erlangga, 2005), hal. 2.

${ }^{13}$ Ali Maksum, "Model Pendidikan Toleransi di Pesantren Modern dan Salaf." Jurnal Pendidikan Agama Islam 3, no. 1 (2015), 82-108. 
Riyan

sebagai pelajar yang diajarkan naskah-naskah arab tentang pembelajaran dan pemahaman akidah keislaman. Ketiga, kiai dan santri tinggal dalam satu lingkungan yang disebut dengan asrama (tempat santri tinggal). ${ }^{14}$ Kiai yang memiliki Pondok Pesantren memiliki wewenang untuk mencetak santri menjadi baik. Aspek-aspek yang diajarkan kiai dalam pesantren adalah aspek keyakinan, peribadatan, wirid dzikir, pengalaman keagamaan, pelatihan mental diri santri, kemandirian personal dan hidup bermasyarakat dengan baik. ${ }^{15}$

Menurut Mastuhu pesantren adalah lembaga pendidikan untuk memahami, menghayati dan mengamalkan ajaran-ajaran agama Islam dengan menekankan pentingnya moral sebagai pedoman hidup bermasyarakat. ${ }^{16}$ Begitu pentingnya moral seorang santri, sehingga kiai berusaha meneruskan tugas yang diamanahkan Allah kepada Nabi Muhammad SAW tentang diutusnya Nabi untuk menyempurnakan akhlak manusia.

Oleh karena itu Pondok Pesantren bertanggung jawab untuk mendidik jiwa santri agar memiliki akhlak yang sesuai dengan Al-Qur'an dan memiliki jiwa kepemimpinan. Pedoman hidup bermasyarakat yang diberikan Pondok pastinya berkaitan dengan kurikulum. Menurut A. Syatori pesantren berperan penting dalam mengembangkan life skill melalui kurikulum yang biasanya kita kenal kurikulum pesantren adalah kurikulum terselubung (hidden curriculum) dimana kiai selalu mengajarkan santri untuk mandiri dengan pembiasaan dalam segala hal diantaranya segi ibadah sholat berjamaah dan melaksanakan sholat sunnah dhuha, segi kebutuhan pribadi seperti mencuci pakaian, memasak, membersihkan tempat pribadi, dan segi sosial kerjabakti, membantu segala kegiatan pondok serta menjaga Pondok Pesantren. ${ }^{17}$

\section{Konsep Kecakapan Hidup}

Konsep kecakapan hidup dirumuskan secara beragam, menurut Nelson Jones dalam Sumirat yang dikutip dari Sutini kecakapan hidup dimaknai sebagai pengetahuan yang luas dan kecakapan sosial yang dibutuhkan bagi manusia untuk dapat hidup secara mandiri. ${ }^{18}$ Kecakapan hidup adalah kemampuan, keberanian dan kemandirian seseorang untuk mengelola problema kehidupan secara lebih baik dan kreatif serta dapat menemukan solusi yang tepat. Pengertian kecakapan hidup secara global sangat luas. Dirjen Kelembagaan Agama Islam mengelompokkan life skill menjadi 4 yaitu pertama, kecakapan individu (personal skill) yang

\footnotetext{
${ }^{14}$ Syamsul Ma'arif, Pesantren Inklusif Berbasis ..., hal. 23.

${ }^{15}$ Abdul Munir Mulkhan, dkk, Rekontruksi Pendidikan dan Tradisi Pesantren (Religiutitas Iptek), (Yogyakarta: FITK UIN Sunan Kalijaga bekerjasama dengan Pustaka Pelajar, 1998), hal. 175.

${ }^{16}$ Syamsul Ma'arif, Pesantren Inklusif Berbasis ..., hal. 20.

${ }_{17}$ A. Syatori, "Modernisasi Pendidikan di Pondok Pesantren Alshighor Gedongan Kecamatan Pangenan Cirebon." Jurnal Holistik 14, no. 2 (2013), 133-156.

${ }^{18}$ Sutini, "Model Pendidikan Keterampilan Hidup (Life Skills) Bagi Anak Putus Sekolah Korban Lumpur Lapindo." Jurnal Pendidikan 15, no. 1 (2014), 54-67.
} 
mencakup kecakapan mengenal diri sendiri (kemandirian), kecakapan berpikir masuk akal, dan percaya diri. Kedua, kecakapan sosial (sosial skill) yaitu kecakapan melakukan kerjasama dengan orang lain, bertenggang rasa, dan tanggung jawab sosial. Ketiga, akademik skill (skill akademik) yaitu kecakapan dalam berfikir secara ilmiah dan melakukan penelitian. Keempat, kecakapan vokasional (vocasional skill) yaitu kecakapan yang dikaitkan dengan bidang pekerjaan tertentu yang terdapat di masyarakat, seperti di bidang jasa (perbengkelan dan jahitmenjahit) dan seperti di bidang produksi barang tertentu (peternakan, pertanian, perkebunan). ${ }^{19}$

Sistem pesantren dapat berkontribusi dalam memberikan rangsangan, dorongan dan motivasi perkembangan santri yang positif, meningkatkan kemandirian pada santri untuk mengatur kehidupannya sendiri. Selain meningkatkan kemandirian, pesantren memberikan sumbangsih menumbuhkan jiwa sosial (solidaritas sosial) pada santri, sebab santri di pesantren hidup berdampingan dengan santri lainnya, santri menenggang rasa sesama santri, belajar hormat menghormati dan menghargai. Sehingga sikap terbuka santri semakin tumbuh dan sikap isolatif semakin memudar. Kiai selaku pendiri pesantren, melalui perannya mampu mengajarkan ilmu-ilmu agama dan uswatun hasanah bagi santri serta masyarakat. Oleh karena itu, pesantren dapat berperan sebagai penggerak dan katalisator pembangunan masyarakat, tidak hanya dalam bidang keagamaan tapi juga dalam bidang kemandirian dan sosial. ${ }^{20}$

\section{Kecakapan hidup personal}

Kecakapan untuk memahami dan menguasai diri merupakan suatu kemampuan yang dibutuhkan sesorang untuk dapat mengaktualisasikan diri serta merawat raga jasmani dan rohani dengan arti lain penghayatan diri sebagai makhluk Tuhan yang Maha Esa. Disamping itu percaya diri (self confidence) meyakinkan pada kemampuan diri sendiri dalam melakukan sesuatu. Pesantren memiliki ciri khas sendiri bahwasanya santri dibimbing dan dituntut untuk tidak mudah mengeluh meskipun dalam kegiatan pesantren yang padat. Salah satu upaya Pesantren untuk melatih mental dan kepercayaan diri santri adalah dengan diadakannya program muhadharah. Muhadharah adalah pelatihan kecakapan santri berbicara didepan orang banyak yang biasa disebut latihan pidato. Pesantren berperan besar dalam mengembangkan kecakapan hidup santri, yang pertama kecakapan hidup personal salah satu bentuk untuk aktualisasi diri dan kemandirian santri. Istilah personal dikenal dengan kepribadian. Sedangkan kata lainnya adalah mentality, individuality dan identity. ${ }^{21}$

\footnotetext{
${ }^{19}$ Departemen Agama RI, Pedoman Integrasi Life ..., hal. 5-7.

${ }^{20}$ Syamsul Ma'arif, Pesantren Inklusif Berbasis ..., hal. 6-7.

${ }^{21}$ Jalaluddin, Psikologi Islam, (Jakarta: RajaGrafindo, 1997), hal. 149.
} 
Riyan

Kemandirian adalah suatu sikap seseorang untuk melakukan atas dorongan sendiri dan memenuhi kebutuhan sendiri tanpa bantuan orang lain, untuk mengurus diri individu dan menyelesaikan masalah apapun secara mandiri. Definisi lain kemandirian adalah sikap atas kemampuan diri sendiri untuk memenuhi kebutuhan pribadi. ${ }^{22}$ Indikator kemandirian adalah tanggung jawab, otonomi dalam menentukan sikap, percaya diri, mampu mengontrol diri, dan mampu membuat keputusan sendiri. ${ }^{23}$ Pesantren memberikan kebebasan santri memilih jalan hidup di masyarakat kelak dan juga menentukan masa depannya. Faktor-faktor yang mempengaruhi kemandirian yaitu gen atau keturunan, sistem pendidikan di sekolah dan sistem kehidupan masyarakat. ${ }^{24}$

\section{Kecakapan hidup sosial}

Di Pesantren kecapakan hidup sosial diajarkan dengan memberikan santri dengan berbagai tugas di masyarakat seperti saling tolong menolong, bekerjasama dalam urusan umum dan menjaga persaudaraan/ukhwah islamiyah sesama makhluk ciptaan Allah. Sebagaimana firman Allah dalam surat Hujurat ayat 10.

Kehidupan di Pesantren selalu diliputi suasana persaudaraan yang sangat akrab, sehingga segala kesenangan dirasakan bersama, dengan jalinan tidak ada dinding yang memisahkan antara mereka meskipun berbeda aliran baik politik sosial dan ekonomi. Fuanuddin T.M berpendapat beberapa cara yang dapat digunakan untuk membentuk sosial yang baik yaitu melalui pembiasaan, keteladanan, nasehat/dialog, dan pemberian penghargaan dan hukuman. ${ }^{25}$ Dan sebaik-baik teladan di muka bumi ini adalah Nabi Muhammad SAW, sebagaimana firman Allah dalam surat Al-Ahzab ayat 21

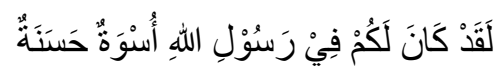

Artinya: Sungguh, telah ada pada (diri) Rasulullah itu suri teladan yang baik bagimu. ${ }^{26}$

Oleh karena itu Kiai berusaha menjadi teladan untuk santri di Pondok Pesantren. Kecakapan sosial ini merupakan kemampuan yang dimiliki sesorang dalam berinteraksi sesama makhluk lainnya dengan baik. Berikut pengertian sosial yang dijabarkan oleh para pakar yaitu pertama, Thomast Ford Hoult, sosial adalah proses individu untuk berinteraksi sesuai dengan standar dalam kebiasaan masyarakat. Kedua, G.H. Mead, sosial adalah sesorang mengadopsi kebiasaan sikap dan ide dari orang lain serta menyusunnya kembali sebagai sistem

\footnotetext{
${ }^{22}$ Najanuddin, 'Pendidikan Kemandirian Berbasis Pesantren', (Skripsi, UIN Sunan Kalijaga, 2013), hal. 49

${ }^{23}$ Najanuddin, 'Pendidikan Kemandirian Berbasis Pesantren',, hal. 51.

${ }^{24}$ Najanuddin, 'Pendidikan Kemandirian Berbasis Pesantren',hal. 52.

${ }^{25}$ Najanuddin, 'Pendidikan Kemandirian Berbasis Pesantren', 30.

${ }^{26}$ Departemen Agama Republik Indonesia, Al-Qur'an ku, ... QS Al-Ahzab: 21, hal. 42o.
} 
dalam diri pribadi. Ketiga, Evert M. Rogers, sosial adalah suatu proses di mana kepribadian seorang individu dibentuk melalui pemindahan budaya terhadap individu. ${ }^{27}$

Pesantren melatih kecakapan sosial dengan mengamanahkan santri untuk berorganisasi dan mengabdi pada masyarakat, disana diajarkan bagaimana mengemukakan pendapat, mengayomi santri sebaya/santri adik tingkat. Santri juga dilatih bagaimana bersikap dengan kiai, ustadz dan masyarakat. Menurut Jalaluddin dalam buku Abdullah idi mengartikan manusia sebagai makhluk sosial yang memerlukan pengembangan potensi manusia agar serasi dengan lingkungan. ${ }^{28}$ Menurut Abraham Maslow kebutuhan psikologis untuk menumbuhkan, mengembangkan dan mengaplikasikan kemampuan seseorang disebut aktualisasi diri. Maslow menemukan kreativitas sebagai ciri universal pada semua orang yang mengaktualisasikan diri. Sifat-sifat yang berhubungan dengan life skill adalah tidak terikat, keberanian, dan tidak mudah takut. Kecakapan hidup personal (mengenal diri sendiri, berfikir) dan sosial merupakan potensi yang dimiliki seorang sejak kecil dan dikembangkan ketika proses bertumbuh dewasa. $^{29}$

\section{Life Skill di Pondok Pesantren Pangeran Diponegoro Yogyakarta}

Kecakapan hidup bertujuan mengembangkan potensi seseorang yang sesuai dengan karakteristik, emosional dan spritual. Di samping itu juga mengembangkan pengetahuan dan kecakapan/keterampilan yang dibutuhkan sesorang untuk bertahan dan meningkatkan kualitas hidup dalam semua lingkungan dengan menggunakan sumber yang telah ada. ${ }^{30}$ Menurut As'ari selaku Kepala Sekolah SMK kecakapan hidup sebagai keterampilan yang dimiliki santri dengan jalan mendidik santri supaya lebih dewasa dalam menghadapi problem dalam hidup. Sebagaimana hasil wawancara dibawah ini

"Life skill merupakan kecakapan atau keterampilan (kemampuan) yang harus dimiliki setiap orang, untuk menghadapi persoalan-persoalan yang terjadi dalam hidup. Kecakapan hidup yang diberikan untuk santri tidak hanya berorientasi untuk duniawi tetapi juga bekal agama yang membantu pribadi santri ketika menghadapi masalah." 31

${ }^{27}$ Muhammad Amin Nur, Islam dan Pembelajarn Sosial, (Malang: UIN Malang Press, 20o9), hal. 12.

${ }^{28}$ Abdullah Idi, Sosiologi Pendidikan, (Jakarta: RajaGrafindo, 2016), hal. 168.

${ }^{29}$ Frank G Goble, Psikologi Humanistik Abraham Maslow, (Yogyakarta: Kanisius, 1987), hal. 53, 77.

$3^{\circ}$ Jamal Ma'mur Asmani, Kiat Melahirkan Madrasah Unggulan, (Yogyakarta: Diva Press, 2013), hal. 132.

${ }^{31}$ Hasil wawancara dengan As'ari selaku Kepala Sekolah diruang kepala Sekolah SMK. 25 September 2018 
Riyan

Kecakapan hidup ini tentunya memberikan banyak manfaat buat santri dan buat orang lain di masa sekarang dan masa depan. Adapun manfaat kecakapan hidup menurut Pengasuh Putri santri Pondok Pesantren Pangeran Diponegoro adalah menjadikan santri lebih dewasa dalam mengatasi masalah-masalah dalam hidup dan pengalaman. Sebagaimana hasil wawancara sebagai berikut

"Pertama Bekal hidup ketika santri ketika keluar pondok hidup sederhana yang sudah diajarkan di pondok dapat diaplikasikan, kedua santri itu lebih dewasa mengatasi masalah karena berbagai macam masalah yang dihadapi ketika di pondok, dan ketiga pengalaman hidup bersama-sama." 32

Oleh karena itu kecakapan hidup santri perlu dikembangkan karena kelebihan dan potensi dalam diri anak sudah Allah berikan ketika hendak dilahirkan dalam dunia. Pondok Pesantren Pangeran Diponegoro selalu berupaya untuk mendidik kecakapan hidup santri sebagai bentuk syukur terhadap nikmat yang telah Allah berikan. Dengan memberikan kecakapan hidup di Pondok, santri benar-benar memahami sang pencipta, diri sendiri, dan orang lain.

\section{Kemandirian}

Pada dasarnya, aktivitas seseorang ditujukan untuk memenuhi kebutuhan diri sendiri baik kebutuhan jasmani, rohani, dan psikologis serta kebutuhan hidup. Pemenuhan kebutuhan tersebut adalah dalam rangka menjalani kehidupannya. Menurut Jannah selaku Pengasuh santri Pondok Pesantren Pangeran Diponegoro Yogyakarta mengungkapkan bahwa kemandirian adalah ketika santri menjalani proses peralihan dari kebiasaan-kebiasaan dirumah untuk membiasakan hidup sederhana di Pondok Pesantren dan bertahan berpisah dengan orang tua.

Pendapat Jannah diatas diperkuat oleh Kiai Syakir Ali Kemandirian merupakan latihan anak untuk menetap di Pondok dan jauh dari orang tua tanpa mengeluh dan terbiasa untuk hidup sederhana. Pendapat lain Khoiruddin sebagai Kepala Sekolah SMP dan As'ari sebagai Kepala Sekolah SMK mengenai kemandirian adalah keterampilan seseorang untuk mengatur diri sendiri tanpa memberatkan dan bergantung dengan orang lain. Contoh santri tidak bergantung dengan orang lain membersihkan tempat tidur, mengambil makan, mencuci pakaian, melakukan sholat jama'ah, dan mengaji setelah sholat, santri mengaji setelah sholat ashar dan Lukman selaku pengasuh membimbing santri. ${ }^{33}$ Semua kegiatan diatas dilakukan dengan pembiasaan yang telah diterapkan Pondok Pesantren Pangeran Diponegoro kepada santri. Untuk memperkuat hasil observasi tersebut yaitu dengan wawancara, sebagaimana hasil wawancara dibawah ini:

\footnotetext{
${ }^{32}$ Hasil wawancara dengan Jannah selaku ustadzah diruang pengasuh. 24 September 2018

${ }^{33}$ Hasil observasi kegiatan santri. 24 September 2018
} 
"Kemandirian santri berproses, pertama akan mengalami peralihan santri yang biasanya dituruti semua keinginannya, kemudian pindah ke pondok yang secara hiduppun dia sudah berpisah dari orang tuanya otomatis dia harus dipaksa hidup dengan mandiri. Mandiri dalam hal apapun mulai dari dalam hal keseharian, makan, minum kemudian mengatur keuangannya, belajarnya mungkin itu dari segi kemandirian."34

Kecakapan kemandirian santri diartikan kemampuan santri dalam penghayatan diri sebagai makhluk ciptaan Allah SWT sebagaimana ungkapan kata-kata hikam Arab "barang siapa yang mengenal dirinya, sesungguhnya dia mengenal Tuhannya" dan menyadari kelebihan kekurangan yang dimiliki sebagai modal dalam meningkatkan kualitas diri agar bermanfaat buat diri sendiri dan orang lain. ${ }^{35}$ Kemandirian adalah dimana keadaan seseorang tidak selalu mengharapkan bantuan kepada orang lain, berusaha sebisa mungkin untuk mengerjakan segala sesuatu sendiri. Kemandirian yang sederhana, meliputi aktivitas seharihari dalam rangka santri tersebut membantu diri sendiri, santri mengatur diri sendiri misalnya santri membersihkan tempat tidur, santri membersihkan lingkungan, santri mengambil makan tanpa menyuruh orang lain, dan santri mencuci pakain sendiri. Ini semua sudah termasuk dalam tatatertib santri. Sebagaimana hasil wawancara berikut

"Kami selaku pengasuh disini membentuk kemandirian santri minimal dari kebutuhan santri sehari-hari yaitu mereka dilarang keras oleh pondok untuk loundry, santri harus mencuci pakainnya sendiri. Kemudian setelah bangun tidur mereka kita wajibkan untuk membersihkan dan merapikan tempat tidurnya sendiri. Ketika makan mereka juga tidak diperbolehkan diambilkan teman, harus mengambil sendiri, disinilah kita sebagai pengasuh membentuk kemandirian santri, minimal kebutuhan pribadi." ${ }^{\prime 36}$

Semua aktivitas ini biasanya dilakukan oleh seseorang ketika masuk pondok pesantren,

karena ketika hendak masuk pesantren berarti sudah menyiapkan mental untuk bisa bertahan di keramaian orang. Bila dilihat lebih luas kemandirian berkaitan dengan kemampuan menyelesaikan masalah yaitu mengambil inisiatif, memecahkan permasalahan sehari-hari, tekun, serta melakukan sesuatu tanpa bantuan orang lain. ${ }^{37}$ Oleh karena itu tidak heran ketika seseorang masuk pesantren, maka yang bersangkutan akan memiliki kapasitas kemandirian lebih unggul jika dibandingkan dengan siswa biasa yang hanya sekolah dan setelah selesai proses belajar mengajar pulang. Sebagaimana hasil wawancara sebagai berikut

"Santri dari dulu sudah terkenal mandiri apalagi jika dibandingkan dengan siswa. Siswa hanya sekedar belajar kemudian pulang sekolah tidak ada lagi kegiatan/aktivitas seperti halnya yang dilakukan santri, yaitu setelah pulang sekolah santri dihadapkan dengan

\footnotetext{
34 Hasil wawancara dengan Jannah selaku Ustadzah di ruang pengasuh. 24 September 2018

35 Jamal Ma'mur Asmani, Kiat Melahirkan Madrasah ..., hal. 133.

${ }^{36}$ Hasil wawancara dengan Zaidun selaku Pengasuh santri di ruang pengasuh. 24 September 2018

${ }^{37}$ Emma-Sue Prince, The Advantage, (Jakarta: Bumi Aksara, 2017), hal. 29.
} 
kegitan rutinitas seperti sholat berjama'ah, madrasah diniyyah pada sore hari dan belajar mandiri pada malam hari", 38

Menurut Steinberg yang diterjemahkan oleh Kusumawardhani dan Hartati dalam karya ilmiah Sri Wahyuni Tanshzil, beberapa aspek kemandirian diantaranya kemandirian emosi, kemandirian bertindak dan kemandirian nilai. Aspek kemandiriaan emosional berfokus pada kemampuan anak untuk melepaskan diri dari ketergantungan orang tua dalam pemenuhan kebutuhan dasar-dasarnya. Aspek kemandirian bertindak adalah kemampuan anak untuk melakukan aktivitas sendiri. Aspek kemandirian nilai adalah kebebasan untuk mengartikan prinsip benar salah, wajib hak, dan yang mana penting dan tidak penting. ${ }^{39}$

Strategi Pondok Pesantren Pangeran Diponegoro dalam membina, melatih dan mengembangkan jiwa kemandirian santri dilakukan dengan pembiasaan, pemberian nasehat, melatih kepemimpinan santri dan keteladanan dari Kiai dan para pengasuhnya. Penjelasan strateginya sebagai berikut pertama, pembiasaan. pembiasaan yang dilaksanakan di Pondok Pesantren Pangeran Diponegoro pada seluruh kegiatan, pembiasaan disini terdiri dari beberapa aspek yaitu pertama pembiasaan dalam beribadah seperti sholat fardhu secara berjamaah, sholat tahajud, sholat dhuha, mengaji dan menghafal sebagian surat dalam Al-Qur'an setelah sholat subuh dan ashar. Penulis telah melakukan observasi, santri putra dan putri melaksanakan sholat dhuha secara berjamaah, dan setelah sholat mereka berdoa bersama-sama. Dalam observasi santri sholat dhuha secara berjama'ah, santri putra terdiri dari dua saff, santri putri dua saff Kegiatan ibadah yang dilakukan santri ini dilakukan setiap hari untuk membiasakan santri sholat sunnah dhuha, yang manfaatnya untuk melancarkan rezeki orang tua santri. Sebagaimana hasil wawancara berikut:

"Santri disini semua aktivitasnya berawal dari pembiasaan yang diinstruksikan oleh ustadz/ustadzahnya, dari harus bangun pagi untuk sholat subuh berjamaah, setelah itu mengaji dan menghafal surat-surat pendek juz 'amma, untuk belajar formal ke sekolah pagi hari kemudian dilanjutkan madrsah diniyyah sore hari sampai belajar mandiri pada malam hari. Seluruh kegiatan santri sudah terjadwal, jadwal yang sudah baku supaya santri terbiasa disiplin."40

Kemudian pembiasaan dalam melakukan aktivitas sehari-hari seperti santri mengambil makan sendiri dan mencuci pakain sendiri. Karena santri dilarang makan dengan diambilkan oleh temannya dan mencuci pakain di loundry. Pembiasaan dalam mengikuti peraturan Pondok

${ }^{8}$ Hasil wawancara dengan As'ari selaku Kepala Sekolah diruang kepala Sekolah SMK. 25 September 2018

39 Sri Wahyuni Tanshzil, "Model Pembinaan Pendidikan Karakter pada Lingkungan Pondok Pesantren dalam Membangun Kemandirian dan Disiplin Santri." Jurnal Penelitian Pendidikan 13, no. 2 (2012), hal. 1-18.

${ }^{40}$ Hasil wawancara dengan Khoiruddin selaku Kepala Sekolah diruang kepala Sekolah SMP. 25 September 2018 
Pesantren seperti pergi ke sekolah dan sore harinya mengikuti kegiatan madrasah diniyyah. Sebagaimana hasil wawancara dibawah ini:

"Bahwasanya pondok pesantren membuat peraturan-peraturan yang mana itu mendidik santri untuk tidak bergantung dengan orang lain. Contoh dalam mencuci pakain, santri dilarang untuk meloundri. Kemudian makan harus ambil sendiri." 41

Seluruh pembiasaan diatas tidak lain bertujuan untuk membentuk kemandirian agar santri santri di Pondok Pesantren Pangeran Diponegoro menjadi sosok yang sederhana, tekun, dan berani dalam menjalani hidup sekarang dan masa depan. Santri yang memiliki jiwa sederhana, ia akan hidup dalam optimis, kegembiraan, dan jauh dari putus asa serta kesedihan yang tidak berguna. ${ }^{42}$

Kedua, pemberian nasihat, Allah dalam surat An-Nahl ayat 125 telah memerintahkan umat manusia untuk saling nasehat menasehati dalam kebaikan yang berbunyi

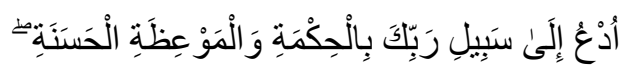

Artinya Serulah (manusia) kepada jalan Tuhan-mu dengan hikmah dan pelajaran yang baik. ${ }^{43}$

Memberi nasehat merupakan strategi Pondok Pesantren Pangeran Diponegoro dalam mengasah kemandirian santri dalam membentuk pribadi yang memiliki jiwa agamis, mengingatkan santri untuk melembutkan hatinya agar tidak mudah putus asa dalam menjalankan hidup. Nasehat yang biasa diberikan Kiai berupa aturan-aturan agama diiringi dengan menyebutkan hukum, janji dan pahala yang diberikan Allah SWT. Kiai memberikan nasehat pada setiap hari sabtu, dan hari minggu dalam kegiatan pengajian ahad pagi. Penulis mengobservasi kegiatan para santri menyiapkan tempat dan mengatur parkir tamu dalam kegiatan pengajian ahad pagi. Kegiatan ini merupakan salah satu strategi Pondok untuk mengembangkan kecakapan hidup santri, dengan nasehat santri menjadi manusia yang lebih baik.

Ketiga, Pondok Pesantren melatih jiwa kepemimpinan santri. Kepemimpinan diri yaitu seseorang yang dapat menaklukkan dan menguasai diri sendiri. Lao Tzu dalam buku Kaswan mengatakan mereka memahami orang lain adalah bijaksana, mengetahui dirinya sendiri adalah cerdas, mengalahkan orang lain adalah kuat dan mengalahkan dirinya sendiri adalah mulia. ${ }^{44}$ Kepemimpinan merupakan kecakapan seseorang untuk memimpin diri sendiri dan orang lain. ${ }^{45}$ Setiap kita adalah pemimpin dan setiap pemimpin akan diminta pertanggung jawabannya.

\footnotetext{
${ }^{41}$ Hasil wawancara dengan santri Risnu di Masjid. 24 September 2018

42 Budhy Munawar Rachman, Pendidikan karakter, (Asia: The Asia Foundation, 2017), hal. 373.

43 Departemen Agama Republik Indonesia, Al-Qur'an ku, ... QS An-Nahl: 125, hal. 281.

${ }^{44}$ Kaswan, 101 Soft Skills, (Bandung: Alfabeta, 2015), hal. 174.

45 Amirullah Haris Budiyono, Pengantar Manajemen, (Yogyakarta: Graha Ilmu, 2004), hal. 243.
} 
Riyan

Pondok Pesantren Pangeran Diponegoro juga melatih kecakapan santri dalam berorganisasi meskipun itu dalam lingkup organisasi kecil. Sebagaimana hasil wawancara dibawah ini

"Pada sore hari dalam kegiatan di madrasah diniyyah santri mengaji, dan mengaji sesuai tingkatan. Adapun tingkatnnya yaitu ula, wustho dan ulya, seluruh tingkatan itu diberikan tanggung jawab sebagai pemimpin kelompok untuk mengatur kegiatan madrasah diniyah dengan harapan madrasah diniyah dapat berjalan dengan baik. ${ }^{46}$ Dengan memberikan tanggung jawab berorganisasi yang di namakan dengan Ikatan Santri Diponegoro. ${ }^{47}$ Pondok mendidik kepemimpinan santri pada setiap kamar, kelas dan tingkat pondok diberikan peluang untuk berorganisasi meskipun dalam lingkup kecil." 48

Pada saat observasi, santri yang bertanggung jawab dalam organisasi Ikatan Santri Diponegoro bagian Ibadah mengkoordinir santri lainnya untuk melaksanakan sholat dhuha berjama'ah. Santri diajarkan Pondok Pesantren untuk belajar mengatur diri dan mengatur orang lain, melatih kepemimpinan santri merupakan salah satu cara melatih kemandirian santri.

Dalam melatih jiwa pemimpin dalam diri minimal diharapkan santri dapat memimpin diri sendiri agar memiliki jiwa percaya diri dan tanggung jawab. Percaya diri sangatlah diperlukan ketika kita dalam menghadapi sesuatu misalkan santri dalam menghadapi ujian, santri harus siap mengerjakan ujiannya dengan kepercayaan dirinya. Disamping santri memiliki percaya diri, santri juga memiliki tanggung jawab, dengan sendirinya ia akan mendapatkan hak yang searah dengan tanggung jawab yang ia emban. ${ }^{49}$ Ketika santri bertanggung jawab dengan belajar sungguh-sungguh berarti dia sudah menjalankan amanahnya pada orang tua, untuk menuntut ilmu di Pondok Pesantren. Sikap tanggung jawab sejak awal ditanamkan kepada santri. Mulai dari tanggung jawab mengatur kebutuhan pribadi atau mengerjakan piket kebersihan sesuai jadwal. Sikap ini dapat dilihat hasil wawancara dibawah ini

"Pak Kiai membuat program kebersihan, bahwasanya di pondok tidak ada yang membersihkannya kecuali penghuni pondok itu sendiri. Kebersihan ini terjadwal sekali yaitu setiap pagi jam 05.00-05.30 dan sore setelah ashar."50

Keempat, keteladanan kiai dan pengasuh (ustadz dan ustadzah). Keteladanan memiliki peranan yang sangat penting dalam pembinaan kemandirian santri. Sebab lingkungan, peran Kiai, ustadz/ustadzah serta teman juga berpengaruh terhadap perubahan-perubahan terhadap santri. Kiai di Pondok Pesantren pangeran Diponegoro selalu memberikan tauladan yang baik

${ }^{46}$ Hasil wawancara dengan Khoiruddin selaku Kepala Sekolah diruang kepala Sekolah SMP. 25 September 2018

${ }^{47}$ Hasil wawancara dengan santri Fahri di Masjid. 24 September 2018

${ }^{48}$ Hasil wawancara dengan santri Risnu di Masjid. 24 September 2018

49 Budhy Munawar rachman, Pendidikan Karakter..., hal. 341.

${ }^{50}$ Hasil wawancara dengan santri Osvaldo Ardiles Hasibuan di Masjid. 24 September 2018 
kepada santri dengan tujuan santri dapat hidup mandiri. Contoh tauladan yang diberikan oleh Kiai dan pengasuh seperti sholat berjama'ah dan mengamalkan ilmu-ilmu agama yang telah diberikan kepada santri maka para santri juga akan mengikutinya. Keteladanan sangatlah penting, sebab membuktikan bahwa apa yang diketahui dan dipelajari para santri dapat dilakukan dan kemudian diamalkan. ${ }^{51}$ Hasil observasi penulis ketika di Pondok, kiai tidak hanya memerintahkan santri membersihkan lingkungan, akan tetapi beliau juga ikut membersihkan masjid yang berada disamping rumahnya. Hasil observasi tersebut diperdalam dengan wawancara sebagai berikut

"Para ustadz/ustadzah memberi contoh dan komando kepada anak. Jadi ustadz/ustadzah tidak hanya semata-mata memerintahkan tetapi mencontohkan dan ikut membantu santri dalam mengasah kemandiriannya. Contoh terkecil sholat jamaah di masjid setiap hari, ketika para ustadz/ustadzah memerintahkan sholat jamaah, mereka juga melakukan apa yang mereka perintahkan." 52

Penulis melihat Ustadz Lukman dan Ustadz Zaidun memerintahkan santri untuk sholat ashar berjama'ah, disamping memerintahkan mereka juga telah siap dengan pakain muslim untuk sholat berjama'ah. Jadi hasil dari pengembangan kemandirian santri banyak dirasakan manfaatnya, tidak hanya dari diri sendiri namun dapat dirasakan juga oleh orang lain. Aspek hasil dari pengembangan kemandirian santri diantaranya aspek ibadah seperti sholat jama'ah sudah mulai terbiasa dan melaksanakan ibadah lainnya. Aspek untuk diri santri dicontohkan seperti tidak menjadi seseorang yang manja ataupun bergantung dengan orang lain, dan menyenangkan hati orang tua. Sebagaimana hasil wawancara sebagai berikut"

"Laporan yang saya terima dari orang tua adalah sebelum masuk pondok anaknya manja dari segala aspek, Alhamdulillah setelah dimasukkan ke pondok pesantren pangeran diponegoro anaknya lebih dewasa dalam bertingkah laku yang sebelumnya harus disuruh dulu sekarang tanpa diperintah sudah melakukan sendiri, pola hidupnya berubah yang biasanya bangun tidur langsung meninggalkan tempat tidur sekarang merapikannya, dalam berbicara sudah tertata rapi dan rumah selalu di sapu setiap hari, bahkan santri yang dulunya malas bangun pagi sekarang pagi-pagi sudah bangun melaksanakan sholat subuh. ${ }^{53}$ Banyak ya, yang saya rasakan pertama mereka masuk berbeda sekali ketika sudah beberapa tahun di pondok. Santri yang diterima di pondok ini notabennya berbagai macam dari anak yang baik, ada yang orang tuanya broken home dan ada juga anak yang memang dari awal nakal. Hasil dari kemandiriannya yang memang awalnya anak itu nakal lama-lama tersadarkan menjadi baik, manja adalah karakter anak ketika setelah dilatih untuk menerima dan mandiri berubah menjadi anak yang bisa mengatur diri sendiri. Anak yang dapat mengatur diri sendiri misalnya dalam hal mencuci pakaian, kegiatan belajar tanpa adanya yang mengatur mereka terbiasa

${ }^{51}$ Mangun Budiyanto dan Imam Machali, "Pembentukan Karakter Mandiri Melalui Pendidikan Agriculture di Pondok Pesantren Islamic Studies Center Aswaja Lintang Songo Piyungan Bantul Yogyakarta.” Jurnal Pendidikan karakter 4, no. 2 (2014), 108-122.

${ }^{2}$ Hasil wawancara dengan Kiai Syakir Ali di rumah beliau. 24 September 2018

53 Hasil wawancara dengan Kiai Syakir Ali di rumah beliau. 24 September 2018 
mengikuti jadwal pondok. Anak yang terbiasa dirumah makan enak lama-lama di pondok terbiasa makan sederhana." 54

\section{Menumbuhkan Jiwa Tolong Menolong}

Ukhwah Islamiyah merupakan pola sosial yang Allah perintahkan untuk membangun nilai iman dan islam. Menurut Theodore Roosevelt dalam buku Kaswan mengemukakan salah satu bahan yang paling penting dalam resep kesuksesan adalah tahu bagaimana caranya untuk berhubungan dengan orang lain. ${ }^{55}$ Manusia sebagai makhluk individu ternyata tidak dapat hidup sendiri dan harus bergantung pada manusia lainnya. Manusia saling membutuhkan dan berinteraksi dengan manusia lainnya, dikarenakan manusia tidak dapat memenuhi kebutuhannya sendiri misal pada saat manusia itu lahir pasti membutuhkan makan dan minum, siapa lagi yang dapat memenuhinya selain orang tuanya sendiri dan kebutuhan manusia yang dasar beras, sayur-sayuran maka akan membutuhkan petani yang menanamnya.

Tolong menolong dalam kebaikan merupakan sesuatu sifat terpuji yang sudah dicontohkan oleh Nabi Muhammad SAW. Pada prinsipnya seseorang tidak dapat sendiri tanpa berbaur dengan orang lain. Meskipun menolong dalam hal sederhana misalkan santri mengambilkan makan buat teman yang sakit, membantu memahamkan teman dalam pelajaran yang tidak dipahaminya. Kehidupan pesantren sebagai subkultur, memang melihatkan kenyataan yang berbeda dan unik bila dibandingkan dengan kehidupan masyarakat diluar pesantren. ${ }^{56}$ Sebagaimana hasil wawancara sebagai berikut

"Pada prinsipnya orang hidup itu tidak bisa sendiri, sama dengan pondok kita, nilai tolong menolong pasti ada dan berlaku. Contoh ketika salah satu santri sakit santri yang lainnya ikut membantu membelikan obat, mengambilkan yang sakit makan. ${ }^{57}$ Saya pernah, teman sakit saya mengambilkan nasi. ${ }^{58}$ Saya pernah, membantu teman pada saat belajar malam, pada pelajaran tertentu yang tidak paham."

Selain tolong menolong seperti mengambilkan makan buat teman yang sakit, dan kerjasama seperti membersihkan pondok/gotong royong sangat diperlukan dalam jiwa santri di Pondok Pesantren Pangeran diponegoro. Dengan adanya jiwa kerjasama maka kegiatan yang diadakan di Pondok dapat berjalan dengan lancar. Sebagaimana observasi yang dilakukan peneliti, santri bekerjasama menyukseskan acara pengajian ahad pagi agenda rutinan pondok, para santri menyiapkan tempat pengajian dan tempat parkir serta penerimaan tamu. Strategi

${ }^{54}$ Hasil wawancara dengan Jannah selaku Ustadzah diruang pengasuh. 24 September 2018

55 Kaswan, 101 Soft Skills ..., hal. 263.

${ }^{56}$ Syamsul Ma'arif, Pesantren Inklusif Berbasis ..., hal. 209.

57 Hasil wawancara dengan As'ari selaku Kepala Sekolah diruang kepala Sekolah SMK. 25 September 2018

${ }^{58}$ Hasil wawancara dengan santri Osvaldo Ardiles Hasibuan di Masjid. 24 September 2018

${ }^{59}$ Hasil wawancara dengan santri Fahri di Masjid. 24 September 2018 
Pondok Pesantren Pangeran Diponegoro dalam mengembangkan kecakapan hidup jiwa sosial santri dari segi tolong menolong dan kerjasama sesama santri yaitu membiasakan peduli dengan orang lain, menjaga kebersamaan, berinteraksi, memiliki jiwa empati dan simpati. Adapun penjelasannya sebagai berikut

Pertama, membiasakan peduli. Pondok Pesantren Pangeran Diponegoro sangat mengedepankan mendidik kepedulian santri, baik kepedulian santri terhadap sesama santri lainnya maupun kepedulian santri dengan lingkungan. Kepedulian merupakan sifat sosial yang didapat santri melalui interaksi sesama teman. Interaksi ini selalu terjadi, misalnya Pondok Pesantren Pangeran Diponegoro memberi pemahaman kepada santri bahwasanya Pondok adalah rumah sendiri, oleh karena itu membersihkannya merupakan tanggung jawab bersama untuk dijaga. Sebagaimana hasil wawancara berikut

"Untuk strategi mengembangkan jiwa sosial, santri diberikan jadwal kebersihan, jadwal kesehatan. Jadwal itu dibuat agar santri saling tolong menolong menjaga kebersihan pondok kemudian adanya jadwal kesehatan setiap santri yang sakit diambilkan nasinya. Meskipun ini sederhana tetapi kebiasaan-kebiasaan seperti ini dapat menjadikan pribadi santri yang memiliki jiwa sosial." 60

Sebagaimana hasil observasi yang telah penulis lakukan, santri bersama-sama bergotong royong membersihkan Pondok Pesantren. Dengan kerjasama dan peduli jiwa sosial santri Pondok Pesantren Pangeran Diponegoro selalu terasah dengan baik. Kerjasama dilaksanakan santri atas dasar saling menghargai. Menghargai, Kasih sayang dan saling berbagi merupakan langkah awal kerjasama. ${ }^{61}$

Kedua, memberi nasihat dan menjaga kebersamaan. Membentuk jiwa sosial anak tidaklah mudah akan tetapi ketika santri telah masuk di Pondok Pesantren Pangeran Diponegoro, tugas pondok mendidik anak dengan totalitas. Di Pondok Pesantren, nasehat dari Kiai perlu diikuti, dan ilmu pertama yang santri dapati adalah ilmu agama, ilmu agama diperjelas dengan ayat-ayat Al-Qur'an. Kemudian merambah ke ilmu sosial yang dikaitkan dengan ilmu agama, contoh Allah memerintahkan manusia untuk saling tolong menolong dalam kebaikan. Sebagaimana firman Allah SWT dalam Al-Qur'an dalam surat Al-Maidah ayat: 2

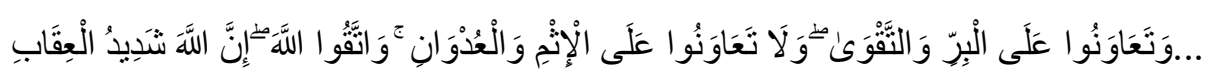

${ }^{60}$ Hasil wawancara dengan Khoiruddin selaku Kepala Sekolah diruang kepala Sekolah SMP. 25 September 2018

${ }^{61}$ Budhy Munawar Rachman, Pendidikan Karakter...,hal. 248. 
Riyan

Artinya "Dan tolong-menolonglah kamu dalam (mengerjakan) kebajikan dan takwa, dan jangan tolong-menolong dalam berbuat dosa dan pelanggaran. Dan bertakwalah kamu kepada Allah, sesungguhnya Allah amat berat siksa-Nya." [al-Ma'idah/5 : 2]. ${ }^{62}$

Dalam memberi nasehat para pengasuh Pondok Pesantren Pangeran Diponegoro tidak hanya sekedar memberi nasehat namun pengasuh harus menjalin kebersamaan sesama santri, jika sudah terjalin jiwa santri dan pengasuh, maka jiwa kebersamaan akan muncul. Ketika jiwa kebersamaan telah terjaga, ketika melakukan apapun seperti membersihkan Pondok, membantu santri dalam belajar akan berjalan dengan lancar, sebagaimana hasil wawancara di Pondok Pesantren Pangeran Diponegoro dibawah ini

"Bentuk konkritnya kita disini pengasuh bersama-sama pada pagi dan sore hari membersihkan lingkungan (gotong royong) pondok pesantren, kita tidak hanya memerintahkan tetapi kita ikut andil membersihkan lingkungan pondok pesantren. Contoh lainnya, pada saat belajar malam, para pengasuh ikut bersama-sama santri belajar dan disana kita dapat membangun kebersamaan." 63

Kebersamaan santri Pondok Pesantren Pangeran Diponegoro dapat dirasakan ketika santri makan bersama ditempat sama dan dengan menu yang sama. Kemudian kebersamaan lainnya ketika salah satu santri mendapat kiriman paket makanan dan lauk pauk dari orang tuanya, mereka saling berbagi karena menjaga kebersamaan. ${ }^{64}$ Kemudian pengurus memberdayakan mereka dengan gotong royong membersihkan kompleks Pondok Pesantren Pangeran Diponegoro. Kebersamaan pada malam jumat santri mengaji dikamar merupakan salah satu menjaga kebersamaan santri. ${ }^{65}$ Jadi tidak mengherankan jika santri terkenal memiliki jiwa sosial yang tinggi, semuanya berawal dari pendidikan di Pondok Pesantren Pangeran Diponegoro. Sebagaimana hasil wawancara sebagai berikut

"Untuk meningkatkan jiwa sosial santri para ustadz dan ustadzah melakukan beberapa hal. Pertama kita pastinya selalu memberikan nasehat, tetapi nasehat yang kita berikan juga kita lakukan sehingga anak-anak tersebut juga melakukannya dengan senang hati. Kedua kita membiasakan santri ketika pondok melakukan kegiatan kita selalu melibatkan santri ini secara tidak langsung mencontohkan santri untuk saling tolong menolong baik menolong kegiatan pondok maupun saling tolong menolong sesama teman. Ketiga kita membiasakan santri untuk saling berbagi ketika mendapat sedikit rezeki seperti paket jajanan ini juga mengasah jiwa tolong menolong santri. Disini kita juga menghimbau santri untuk menyedekahkan sedikit hartanya untuk orang-orang yang kurang mampu." 66 Ketiga, berinteraksi. Pada saat penulis melakukan observasi, santri berkomunikasi dengan kiai Syakir Ali di Masjid Al-Husna. Hubungan dan interaksi antara santri dengan warga

${ }^{62}$ Departemen Agama Republik Indonesia, Al-Qur'an ku ..., QS Al-Maidah: 2, hal. 106.

${ }^{63}$ Hasil wawancara dengan Zaidun selaku Pengasuh diruang pengasuh. 24 September 2018

${ }^{64}$ Mangun Budiyanto dan Imam Machali, "Pembentukan Karakter Mandiri ..., hal. 119.

${ }^{6}$ Hasil Observasi ketika santri menjaga kebersamaan dengan mengaji bersama. 24 September 2018

${ }^{66}$ Hasil wawancara dengan Jannah selaku ustadzah diruang pengasuh. 24 September 2018 
Pondok Pesantren Pangeran Diponegoro mencitrakan pola hubungan yang harmonis dan penuh persaudaraan. ${ }^{67}$ Sebagai makhluk sosial, tidak dapat pungkiri bahwasanya manusia tidak dapat hidup jika tidak berhubungan dengan orang lain. Untuk itu manusia membutuhkan interaksi dengan manusia lainnya yang nantinya memberikan manfaat timbal balik antar individu lainnya. ${ }^{68}$

Apalagi dalam kehidupan santri Pondok Pesantren Pangeran Diponegoro dimana santri tidak bisa hidup sendiri. Tanpa berinteraksi santri akan merasakan asing. Dalam kehidupan Pesantren terlihat santri memiliki rasa kekeluargaan dan kekerabatan yang sangat erat. Sehingga eratnya hubungan antar santri menyebabkan adanya pernyataan milik pribadi menjadi milik bersama. Sikap yang ditunjukkan santri tersebut dalam psikologi disebut dengan sikap prososial. ${ }^{69}$ Arbadiati dalam karya Zamzami Sabiq dan M. As'ad Djalali berpendapat bahwa setiap santri memiliki kecerdasan emosi, mempunyai kemampuan dalam merasakan emosi, mengelola dan memanfaatkan emosi secara tepat sehingga memberikan kelancaran dalam menjalani kehidupan sebagai makhluk sosial. ${ }^{70}$ Contoh santri saling berinteraksi yaitu santri berkomunikasi dan tidak menyakiti satu sama lainnya. Sebagaimana hasil wawancara dengan Pak Kiai Syakir Ali sebagai berikut

“Anak sejak masuk ke asrama sudah belajar bagaimana hidup bersama seperti tinggal bersama-sama teman di asrama, menahan diri seperti tidak membawa HP, saling tolong menolong seperti membantu teman kesusahan dalam belajar dan tidak menyakiti teman lainnya seperti berkelahi. Anak dididik agar tidak menyakiti sesama teman, menyakiti guru maupun orang tua dan menghormati semuanya. Kecakapan hidup adalah bagaimana menanamkan dalam diri anak untuk mengelola emosi secara baik dengan memberikan ilmu akhlak, memberikan pemahaman ketika orang lain menyakiti dirinya sakit, berarti tidak boleh saling menyakiti."71

Keempat, memiliki jiwa empati dan simpati. Pondok Pesantren Pangeran Diponegoro juga menanamkan ke jiwa santri untuk bersikap simpati dan empati baik kepada sesama santri maupun orang lain (masyarakat). Menurut Hurlock dalam karya Gusti Yuli Asih dan Margaretha Maria Shinta Pratiwi empati adalah kemampuan seseorang untuk memahami orang

${ }^{67}$ Syamsul Ma’arif, Pesantren Inklusif Berbasis ..., hal. 209.

${ }^{68}$ Zamzami Sabiq dan M. As'Ad Djalali, "Kecerdasan Emosi, Kecerdasan Spritual dan Perilaku Prososial Santri Pondok Pesantren Nasyrul Ulum Pamekasan.” Jurnal Psikologi Indonesia 1, no. 2 (2012), $53-65$.

69 Zamzami Sabiq dan M. As'Ad Djalali, "Kecerdasan Emosi, Kecerdasan Spritual dan Perilaku Prososial Santri, hal. 54.

$7^{\circ}$ Zamzami Sabiq dan M. As'Ad Djalali, “Kecerdasan Emosi, Kecerdasan Spritual dan Perilaku Prososial Santri, hal. 55 .

${ }^{71}$ Hasil wawancara dengan Kiai Syakir Ali dirumah beliau. 24 September 2018 
Riyan

lain, dan membayangkan diri sendiri membutuhkan bantuan orang lain. ${ }^{72}$ Simpati adalah melakukan sesuatu untuk orang lain, dengan menggunakan cara yang baik, menyenangkan, dan benar. ${ }^{73}$ Strategi yang dilakukan Pondok Pesantren yaitu dengan membiasakan santri infaq setiap pagi sebelum berangkat ke Sekolah. Penulis melihat santri menginfaqkan sedikit uang jajannya dikotak amal. Uang infaq ini dikumpulkan dan dibagikan kepada santri yang kurang mampu, ini juga melatih jiwa simpati dan empati santri karena di Pondok Pesantren Pangeran Diponegoro ada beberapa anak panti asuhan yang diasuh oleh Pondok Pesantren. Sebagaimana hasil wawancara sebagai berikut:

"Kita setiap kamar ada infak, membiasakan diri untuk saling memberi meskipun sedikit." 74

Jadi di Pondok Pesantren Pangeran Diponegoro membiasakan santri untuk menyisihkan sebagian uang jajan yang diberikan orang tua mereka, uang tersebut untuk membantu santri lainnya yang membutuhkan. Dari kebiasaan bersedekah ini secara langsung tanpa disadari mereka membiasakan diri bagaimana menolong orang lain. Menginfaqkan sebagian harta santri tidak akan mengurangi hartanya akan tetapi Allah akan membalasnya dan memberikan sedikit hartanya salah satu bentuk mencintai saudaranya, jika ia sudah mencintai saudaranya seperti ia mencintai dirinya maka sempurnalah imannya sebagai mana hadist nabi Muhammad SAW

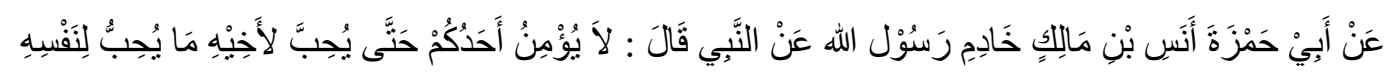
Artinya: Dari Abu Hamzah Anas bin Malik, khadim (pembantu) Rasulullah Shallallahu 'alaihi wa sallam, dari Nabi Shallallahu 'alaihi wa sallam, Beliau berkata, "Tidaklah seseorang dari kalian sempurna imannya, sampai ia mencintai untuk saudaranya sesuatu yang ia cintai untuk dirinya", 75

Program lainnya untuk menumbuhkan jiwa simpati dan empati santri adalah setelah tamat SMP para santri tidak langsung diliburkan akan tetapi mereka akan melewati fase-fase pengabdian langsung kepada masyarakat. Melatih santri merasakan bahwa pemahaman masyarakat kurang ilmu agama. Santri Pondok Pangeran Diponegoro akan tinggal di Masjidmasjid sekitar Pondok untuk mengabdikan diri sebagai bentuk simpati dan empatinya kepada

${ }^{72}$ Gusti Yuli Asih dan Margaretha Maria Shinta Pratiwi, "Perilaku Prososial Ditinjau dari Empati dan Kematangan Emosi." Jurnal Psikologi Universitas Muria Kudus 1, no. 1 (2010), 33-42.

73 Bimo Walgito, Psikologi Sosial, (Yogyakarta: ANDI, 2003), hal. 73.

${ }^{74}$ Hasil wawancara dengan santri Fahri di Masjid. 24 September 2018

75 Imam Nawawi, Terjemah Riyadhus Shalihin, Penj Muslich Shabir, (Semarang: Karya Toha Putra, 2004), hal. 117 . 
masyarakat. Kegiatan ini berlangsung tiga bulan, kemudian bentuk aktivitas santri disana seperti halnya takmir Masjid. Bukti dari pernyataan ini dilihat dari wawancara sebagai berikut

"Strategi pondok pesantren untuk mengembangkan jiwa sosial santri adalah pertama sebelum pembelajaran dimulai santri dibiasakan untuk infaq setiap pagi, strategi ini sangat ampuh untuk mengembangkan jiwa sosial santri. Strategi kedua setelah lulus kelas $3 \mathrm{SMP} / 3 \mathrm{SMK}$ santri disebar ke masjid-masjid sekitar daerah pondok pesantren pangeran diponegoro untuk melakukan kegiatan sosial yang disebut PKL. Mereka disana menjadi takmir masjid selama tiga bulan membersihkan, menjadi imam masjid, khotib ketika jum'at dan menjaga masjid. Mereka diawasi dengan para pembimbing dari para ustadz. ${ }^{76}$ Program sosial yaitu santri kelas 3 SMP disebarkan ke masjid-masjid sekitar pondok untuk mengamalkan ilmu yang didapatkan selama 3 tahun menjadi santri. Santri ditempatkan selama 3 bulan disana untuk mengabdi kepada masyarakat, mulai dari menjaga kebersihan masjid, mengajarkan anak-anak TPA, serta azan dan menjadi imam bagi yang memiliki hafalan dan bacaan yang baik.",77

Kemudian aktivitas lainnya untuk menumbuhkan jiwa simpati dan empati santri adalah

berbaur dengan masyarakat serta Pondok Pesantren memberikan wadah santri untuk membuka tempat produksi tatabusana dan bengkel serta tempat pencucian motor gratis. Disini para santri dilatih untuk membantu masyarakat setempat dan seluruh warga Pondok Pesantren Pangeran Diponegoro untuk mencuci motornya secara gratis. Ungkapan ataupun data ini diperkuat dari hasil wawancara sebagai berikut

"Kita membiasakan santri memiliki jiwa sosial yaitu membuka cuci motor gratis buat masyarakat maupun warga pondok pesantren pangeran diponegoro. Kegiatan sosial ini dilakukan setiap hari, awalnya ketika louncing pertama kali servis motor dan cuci motor gratis ini berlangsung sampai 3 bulan kemudian cuci motor sampai saat ini tetap gratis dan servisnya membayar sesuai dengan servisannya. Kemudian kita juga membuka tempat menjahit yang dinamakan Unit Produksi ini secara tidak langsung kita membantu masyarakat yang hendak menjahitkan pakaiannya, semua ini kita lakukan untuk meningkatkan jiwa sosial santri." 78

Semua yang dilakukan santri pasti ada dampaknya dan hasilnya, adapun hasil dari strategi pengembangan kecakapan hidup sosial santri Pondok Pangeran Diponegoro secara keseluruhannya adalah mereka terlatih untuk peduli lingkungan, peka terhadap yang lain dan sifat individual santri mulai terkikis dengan terbiasanya untuk saling berbagi. Laporan ini juga didapat dari orang tua. Orang tua berterimakasih karena pendidikan Pondok Pesantren berbekas dalam diri anak. Pernyataan ini juga diperkuat dengan wawancara sebagai berikut:

"Tumbuhnya sifat kepekaan santri terhadap lingkungan, adanya sifat simpati dan empatinya sesama teman. Misal teman ada yang sakit, mereka langsung mengambilkan

${ }^{76}$ Hasil wawancara dengan Kiai Syakir Ali dirumah beliau 24 September 2018

77 Hasil wawancara dengan Khoiruddin selaku Kepala Sekolah diruang kepala Sekolah SMP. 25 September 2018

${ }^{78}$ Hasil wawancara dengan As'ari selaku Kepala Sekolah diruang kepala Sekolah SMK. 25 September 2018 
makan ataupun sarapan temannya yang sakit tersebut. ${ }^{79}$ Alhamdulillah saya sendiri benar-benar tertata jiwa sosial saya semenjak masuk pesantren. Saya jujur awalnya cuek terhadap lingkungan namun berjalannnya waktu saya terbiasa hidup bersama-sama dengan santri lainnya. ${ }^{80}$ Saya merasakan simpati dan empati dengan teman-teman di Pondok, karena persahabatan di Pondok sangat erat sekali, bagaimana tidak erat kita 24 jam bersama melakukan berbagai aktivitas bersama." 81

\section{Kesimpulan}

Dari hasil penelitian yang telah penulis lakukan dapat disimpulkan bahwa, Strategi pengembangan kecakapan hidup personal santri tentang kemandirian adalah dengan memberi bekal berupa nasehat tentang eksistensi diri dan membiasakan santri untuk melakukan segala kebutuhan sendiri. Kemudian memberikan pelatihan kepemimpinan dengan mewadahi para santri dalam organisasi yang diberi nama Ikatan Santri Diponegoro (IKASANDIP). Strategi terakhir yaitu keteladanan seorang kiai, karena kiai di Pondok Pesantren menjadi panutan para santri dalam berperilaku. Strategi pengembangan kecakapan hidup sosial tentang tolong menolong dan kerjasama adalah membiasakan santri peduli terhadap santri lainnya, menjaga kebersamaan, berinteraksi, memiliki sikap simpati dan empati serta memberikan nasehat ilmu akan pentingnya tolong menolong.

Hasil yang dirasakan setelah adanya beberapa pengembangan kecakapan hidup personal dan sosial adalah pondok pesantren dan orang tua santri bangga karena pendidikan pondok membuat anaknya berubah menjadi mandiri dari segala aspek terutama mandiri dalam beribadah sholat lima waktu, tidak perlu disuruh-suruh lagi dan jiwa sosial/ kepekaannya/kepeduliaanya terhadap lingkungan semakin terasah, seperti membersihkan lingkungan rumah karena di pondok dibiasakan membersihkan lingkungan pondok.

${ }^{79}$ Hasil wawancara dengan Jannah selaku Ustadzah diruang pengasuh. 24 September 2018

${ }^{80}$ Hasil wawancara dengan santri Osvaldo Ardiles Hasibuan di Masjid. 24 September 2018

${ }^{81}$ Hasil wawancara dengan santri Risnu di Masjid. 24 September 2018 


\section{Daftar Pustaka}

Abdullah Idi, Sosiologi Pendidikan, Jakarta: RajaGrafindo, 2016.

Anonim, Undang-Undang Republik Indonesia Nomor 20 Tahun 2003 tentang SISDIKNAS dan Peraturan Pemerintah R.I Tahun 2013, Bandung: Citra Umbara, 2014.

Arnady, Muhammad Adil dan Lis Prasetyo. "Evaluasi Program Kecakapan Hidup di Sanggar Kegiatan Belajar Bantul Yogyakarta", Jurnal Pendidikan dan Pemberdayaan Masayarakat 3, no. 1 (2016), 60-74.

Asih, Gusti Yuli dan Margaretha Maria Shinta Pratiwi, "Perilaku Prososial Ditinjau dari Empati dan Kematangan Emosi”, Jurnal Psikologi Universitas Muria Kudus 1, no. 1 (2010), 33-42.

Asmani, Jamal Ma'mur. Kiat Melahirkan Madrasah Unggulan, Yogyakarta: Diva Press, 2013. Budiyanto, Mangun dan Imam Machali, "Pembentukan Karakter Mandiri Melalui Pendidikan Agriculture di Pondok Pesantren Islamic Studies Center Aswaja Lintang Songo Piyungan Bantul Yogyakarta.” Jurnal Pendidikan karakter 4, no. 2 (2014), 108-122.

Budiyono, Amirullah Haris. Pengantar Manajemen, Yogyakarta: Graha Ilmu, 2004.

Departemen Agama Republik Indonesia, Al-Qur'an ku, (Jakarta: Lautan Lestari, 2010), QS AlBaqarah: 30.

Departemen Agama RI, Pedoman Integrasi Life Skills terhadap Pembelajaran Madrasah Aliyah, Jakarta: Direktorat Jendral Kelembagaan Agama Islam, 2005.

Fadillah, M Kharis. "Manajemen Mutu Pendidikan Islam di Pesantren (Studi di Pondok Modern Darussalam Gontor).” Jurnal At-Ta'dib 10, no. 1 (2015), 115-137.

Goble, Frank G. Psikologi Humanistik Abraham Maslow, Yogyakarta: Kanisius, 1987.

Herimanto dan Winarno, Ilmu Sosial dan Budaya Dasar, Jakarta : Bumi Aksara, 2010.

Jalaluddin, Psikologi Islam, Jakarta: RajaGrafindo, 1997.

Jannah, Fathul. "Pendidikan Islam dalam Sistem Pendidikan Nasional." Jurnal Dinamika Ilmu 13, no. 2 (2013), 161-173.

Kaswan, 101 Soft Skills, Bandung: Alfabeta, 2015.

Ma'arif, Syamsul. Pesantren Inklusif Berbasis Kearifan Lokal, Yogyakarta: Kaukaba Dipantara, 2015.

Maksum, Ali. "Model Pendidikan Toleransi di Pesantren Modern dan Salaf." Jurnal Pendidikan Agama Islam 3, no. 1 (2015), 82-108.

Marwiyah, Syarifatul. “Konsep Pendidikan Berbasis Kecakapan Hidup.” Jurnal Falasisfa 3, no. 1 (2012), 75-97. 
Riyan

Mawardi, Imam. "Pendidikan Life Skills Berbasis Budaya Nilai-Nilai Islami dalam Pembelajaran.” Jurnal Pendidikan Islam 6, no. 2 (2012), 215-230.

Megarani, Risqi Respati Suci. 'Strategi Pemberdayaan Santri di Pondok Pesantren Hidayatullah Donoharjo Ngaglik Sleman Yogyakarta'. Skripsi, UIN Sunan Kalijaga, 2010.

Mulkhan, Abdul Munir, dkk. Rekontruksi Pendidikan dan Tradisi Pesantren (Religiutitas Iptek), Yogyakarta: FITK UIN Sunan Kalijaga bekerjasama dengan Pustaka Pelajar, 1998.

Mutohar, Ahmad dan Nurul Anam, Manifesto Modernisasi Pendidikan Islam \& Pesantren, Yogyakarta: Pustaka Pelajar, 2013.

Najanuddin, 'Pendidikan Kemandirian Berbasis Pesantren', Skripsi, UIN Sunan Kalijaga, 2013.

Nawawi, Imam. Terjemah Riyadhus Shalihin, Penj Muslich Shabir, Semarang: Karya Toha Putra, 2004.

Ni'mah, Shofwatin. 'Pelaksanaan Pendidikan Life Skills di Pondok Pesantren Darul Falah Be-Songo Ngaliyan Semarang'. Skripsi, Institut Agama Islam Negeri Walisongo, 2012.

Nur, Muhammad Amin. Islam dan Pembelajarn Sosial, Malang: UIN Malang Press, 2009.

Prince, Emma-Sue. The Advantage, Jakarta: Bumi Aksara, 2017.

Qomar, Mujamil. Pesantren dari Transformasi Metodologi Menuju Demokratisasi Instutusi, Jakarta: Erlangga, 2005.

Rachman, Budhy Munawar. Pendidikan karakter, Asia: The Asia Foundation, 2017.

Sabiq, Zamzami dan M. As’Ad Djalali, “Kecerdasan Emosi, Kecerdasan Spritual dan Perilaku Prososial Santri Pondok Pesantren Nasyrul Ulum Pamekasan”, Jurnal Psikologi Indonesia 1, no. 2 (2012), 53-65.

Sanusi, Uci. "Pendidikan Kemandirian di Pondok Pesantren.” Jurnal Pendidikan Agama Islam 10, no. 2 (2012), 123-139.

Sayogya, Tut. Sukses Berbasis Talenta Alami, Jakarta: PT Elex Media Komputendo, 2011.

Sutini, "Model Pendidikan Keterampilan Hidup (Life Skills) Bagi Anak Putus Sekolah Korban Lumpur Lapindo.” Jurnal Pendidikan 15, no. 1 (2014), 54-67.

Suyitno, Imam. "Pengembangan Pendidikan Karakter dan Budaya Bangsa Berwawasan Kearifan Lokal.” Jurnal Pendidikan Karakter 2, no. 1 (2012), 1-13.

Syatori, A. "Modernisasi Pendidikan di Pondok Pesantren Alshighor Gedongan Kecamatan Pangenan Cirebon.” Jurnal Holistik 14, no. 2 (2013), 133-156. 
Implementasi Kemandirian dan Jiwa Sosial (Life Skills) Santri di Pesantren

Tanshzil, Sri Wahyuni. "Model Pembinaan Pendidikan Karakter pada Lingkungan Pondok Pesantren dalam Membangun Kemandirian dan Disiplin Santri." Jurnal Penelitian Pendidikan 13, no. 2 (2012), hal. 1-18.

Walgito, Bimo. Psikologi Sosial, Yogyakarta: ANDI, 2003. 